\title{
Evaluation of the Maturity of the Compost Produced at the Compost Production Site of the NGO ENPRO in Lomé (Togo) Using the UV-Visible Spectroscopy
}

\author{
Joël Mawuli Tamakloe ${ }^{1}$, Edem Komi Koledzi ${ }^{1, ~ *, ~ S a s s o u ~ M e g n a s s a n ², ~ E t s e ̀ ~ A z i a b l e ~}{ }^{1}$ \\ ${ }^{1}$ Laboratory of Management, Treatment and valuation of Waste (GTVD), Department of Chemistry, University of Lomé, Lomé, Togo \\ ${ }^{2}$ Laboratory of Process Engineering and Natural Resources (LAGEPREN), Department of Chemistry, University of Lomé, Lomé, Togo
}

Email address:

edemledzi@yahoo.fr(E.K. Koledzi)

${ }^{*}$ Corresponding author

To cite this article:

Joël Mawuli Tamakloe, Edem Komi Koledzi, Sassou Megnassan, Etsè Aziable. Evaluation of the Maturity of the Compost Produced at the Compost Production Site of the NGO ENPRO in Lomé (Togo) Using the UV-Visible Spectroscopy. Science Journal of Chemistry.

Vol. 8, No. 4, 2020, pp. 95-101. doi: 10.11648/j.sjc.20200804.14

Received: August 18, 2020; Accepted: August 31, 2020; Published: September 17, 2020

\begin{abstract}
Composting is a method of recovery of household solid waste. But to be useful to agriculture the compost resulting from this process must be mature. The objective of this study is to evaluate the maturity of three types of composts produced on the garbage composting unit of the NGO ENPRO in Lomé. Three types of compost (garbage, fruit waste, animal litter) were made in windrows for at least 3 months. The maturity of the composts was determined according to the basic chemical analysis, by UV-Visible spectroscopy. UV-visible spectroscopy performed on the three types of compost at the end of the 3rd and 4th months of composting shows a decrease in the E4/E6 ratio $(465 \mathrm{~nm} / 665 \mathrm{~nm}), \mathrm{Q} 2 / \mathrm{Q} 6(280 \mathrm{~nm} / 664 \mathrm{~nm})$ and Q4/Q6 (472 nm/664 nm) for two types of composts characteristic of increasing humification of organic matter. The data from the various elementary analyzes and particularly from UV-Visible spectroscopy show that composts $\mathrm{N}^{\circ} 1$ and $\mathrm{N}^{\circ} 2$ can be considered ripe after 3 months of composting. But the values of the various elementary analyzes clearly show that compost $\mathrm{N}^{\circ}$ 3 is not yet ripe. UV-Visible spectroscopy is a relatively effective method for evaluating the maturity of compost.
\end{abstract}

Keywords: Compost, Spectroscopy, UV-Visible, Household Waste, Absorbance

\section{Introduction}

The management of household waste represents a permanent challenge both for the public authorities and for the households which produce this waste. On the basis of a production of $0.91 \mathrm{~kg} /$ person/day, the quantity of household waste produced in the district of Lomé is estimated at 800 tons every day [1]. Despite the efforts of the public authorities, through the Town Hall of the city of Lomé, there are still significant proportions of unauthorized dumps. Due to the fact that the vast majority of these wastes are putrescible hence compostable (55\% to $65 \%)$, it is necessary and even essential to transform it. Consequently, it helps to improve agronomic yields [2]. Through the financing of the French Global Environment Facility (FGEF), the Region Iles de France, the Suez Environmental Fund, SYCTOM (central mixed union for the treatment of household waste) and the
Town Hall of Lomé, a composting production facility has been set up in Lomé in 2011 with technical support from the GTVD Laboratory and the French association GEVALOR in order to give a second life to the vast majority of waste produced in homes. The AFRICOMPOST program (production of compost in 6 African cities), which represents an important lever for the recovery of waste in developing countries, came to the fore in 2012 . With nearly fifty workers recruited from disadvantaged social strata, this platform managed by the NGO ENPRO treats 20 to 25 tons of waste per day and produces compost for farmers. Despite the annual analyzes performed on the composts produced on this site, user reports indicate a doubt about the maturity of these composts. This study aims is to use other performance analyzes such as UV-Visible spectroscopy in addition to 
those performed annually to assess the maturity of the composts produced on the platform of the NGO ENPRO in Lomé.

\section{Materials and Methods}

\subsection{Types of Composted Waste}

Five tons of household garbage were collected at the source (households, fruit processing company, cattle market) and transported to the composting site of the NGO ENPRO. Household garbage is first sorted and fermentable organic matter is recovered; fruit waste and animal litter are used as collected.

\subsection{Waste Composting}

The selected site is the composting site of the NGO ENPRO located in the district of Adidogomé in Lomé in Togo.

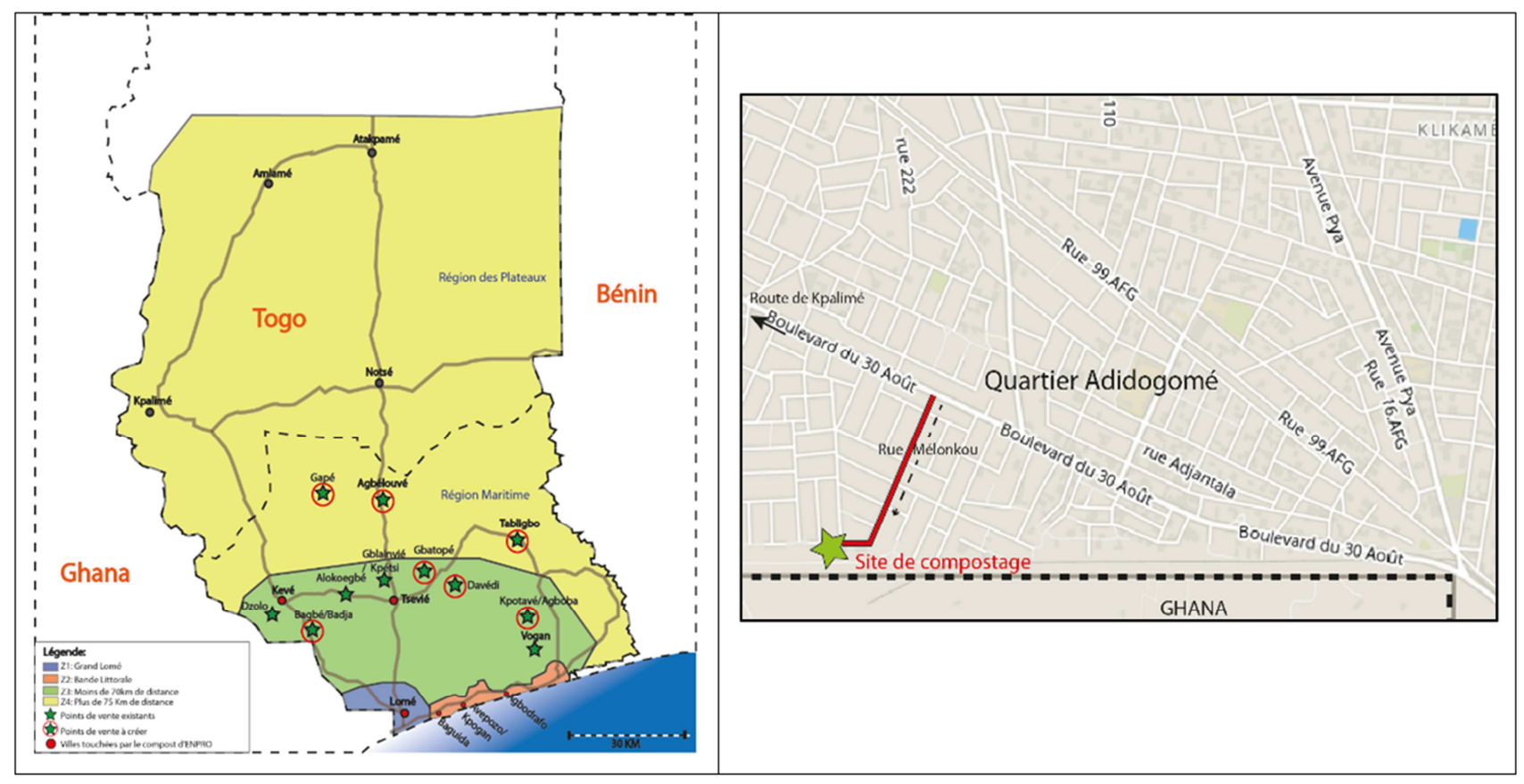

Figure 1. Urban waste composting site in Lomé, Togo.

Three types of compost have been produced from this waste: compost $\mathrm{N}^{\circ} 1$ composed of household waste, compost $\mathrm{N}^{\circ} 2$ composed of $50 \%$ pineapple waste and $50 \%$ household waste, compost $\mathrm{N}^{\circ} 3$ composed of animal litter and straw. Each type of compost is duplicated.

The swath composting method was chosen for this study because it is the method used on the site. $600 \mathrm{~kg}$ of waste is used for each type of compost and arranged in a pile (swath). Waste was turned over on the 3rd, 10th, 22nd, 36th and 71st days after the launch. This is to ventilate the heaps and allow better degradation of organic matter. During the composting process, the temperature was measured every day (from the 1 st to the 107 th day) using electronic thermometers equipped with a 50 to $90 \mathrm{~cm}$ penetration probe.

\subsection{Evaluation of the Chemical Parameters of Composts (Elementary Analyzes)}

After 3 and 4 months of composting, compost samples (2 heaps per category), taken from different places in the heaps, were screened on a sieve with a $5 \mathrm{~mm}$ mesh. Each sample analyzed is a mixture of two composts from the same category.

The humidity is determined after drying in an oven at $60^{\circ} \mathrm{C}$ to constant weight.
After grinding and sieving at $2 \mathrm{~mm}$ the $\mathrm{pH}$ (international standard ISO 10390, 1994), the electrical conductivity (standard ISO 11265, 1994), the total organic carbon (Walkley and Black), the total nitrogen Kjeldahl, the total phosphorus (attack perchloric acid) have been determined. Atomic absorption spectroscopy was used to determine the total concentrations of $\mathrm{K}, \mathrm{Ca}, \mathrm{Mg}, \mathrm{Na}$, and metallic trace elements $(\mathrm{Cu}, \mathrm{Zn}, \mathrm{Cd}, \mathrm{Ni}, \mathrm{Pb}$, and $\mathrm{Cr})$. This after mineralization of the compost samples with a mixture of acids: $\mathrm{HNO}_{3}, \mathrm{HClO}_{4}$ and $\mathrm{HF}$. The residues are then taken up with $\mathrm{HNO}_{3}$ and $\mathrm{HCl}$ (SAA, 2003).

\subsection{Evaluation of the Maturity of Composts Produced Using Spectroscopic Methods}

The maturity of the three types of composts was evaluated essentially using UV-Visible spectroscopy. The principle of this method is based on the measurement of different absorbance ratios relating to the amounts of humic and fulvic acids in the compost. Researches have shown that the alkaline spectra of composts have three main regions: 260$280 \mathrm{~nm}$ for quinones, $460-480 \mathrm{~nm}$ for organic matter at the start of humidification and 600-670 nm for highly humified matter [3]. This distribution makes it possible to measure the absorbance Q2 (280 nm), Q4 (472 nm) and Q6 (664 nm). Of 
this absorbance, the ratios Q2/Q6, Q4/Q6 and Q2/Q4 are calculated because they are considered as indices of humidification of the composts. The Q2/Q6 and Q4/Q6 ratios indicate the content of highly humidified organic matter in the compost and the humidification of organic matter.

The absorbance E4 $(445 \mathrm{~nm})$ and E6 $(665 \mathrm{~nm})$ are also measured. The report ratio E4/E6 ([4-7] makes it possible to evaluate the quality of the compost.

\subsubsection{E4/E6 Experimental Protocol}

$25 \mathrm{mg}$ of dry compost is added to $25 \mathrm{ml}$ of sodium bicarbonate solution $\left(\mathrm{NaHCO}_{3}\right)$ at $0.05 \mathrm{~mol}$. $\mathrm{L}^{-1}$. The resulting solution should have a $\mathrm{pH}$ close to 8 . Stir for 2 hours using a magnetic stirrer. After a few minutes' rest, take the supernatant and centrifuge it at $300 \mathrm{rpm}$ for $25 \mathrm{~min}$. Then measure the light absorption at frequencies of $465 \mathrm{~nm}$ (E4) and $665 \mathrm{~nm}$ (E6). The values obtained allow the E4/E6 ratio to be calculated [8].

\subsubsection{Experimental Protocol Q2/Q6, Q4/Q6 and Q2/Q4}

$1 \mathrm{~g}$ of dry compost is added to $50 \mathrm{~mL}$ of $0.5 \mathrm{~N}$ sodium hydoxide $(\mathrm{NaOH})$. The whole is stirred for 2 hours using a magnetic stirrer and then left to stand for a few minutes. The supernatant is then removed before being centrifuged at 300 $\mathrm{rpm}$ for $25 \mathrm{~min}$. The final step is to measure absorbance at $280 \mathrm{~nm}$ (Q2), $472 \mathrm{~nm}$ (Q4), $664 \mathrm{~nm}$ (Q6) using a UV-Visible spectrometer. The different absorbance values obtained make it possible to calculate the ratios Q2/Q6, Q4/Q6, Q2/Q4 [3].

\section{Results}

At the end of the maturation, the composts obtained are characterized by an absence of ammonia odor, a temperature close to ambient temperature, a grainy, dark appearance and pleasant odor. We also note the appearance of woodlice as well as other types of arthropods and the absence with the naked eye of the compounds of the original substrates.

\subsection{Different Temperatures During the Composting Process}

Figure 2 shows the temperature evolution of the three types of compost over a period of 107 days.

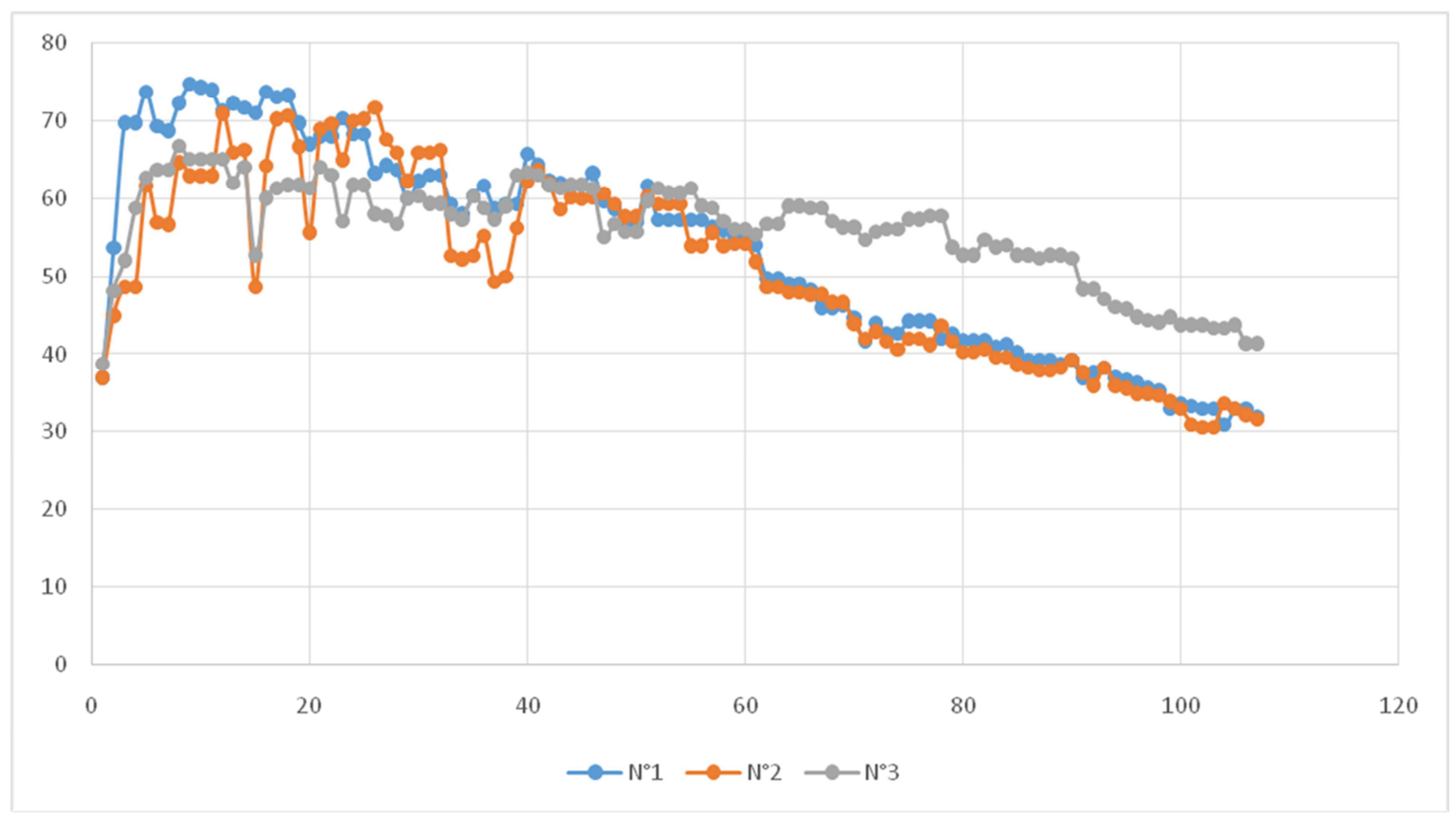

Figure 2. Different temperatures during the composting process.

\subsection{Determination of $\mathrm{pH}$ and Electrical Conductivity of Composts}

Table 1 shows the evolution of the $\mathrm{pH}$ and the electrical conductivity of the three types of compost produced. The $\mathrm{pH}$ of the composts after 3 months of composting is between 8.1 and 8.3. This $\mathrm{pH}$ decreases at the end of the 4th month of composting for the three types of compost studied. The electrical conductivity is between 3.4 and $8.0 \mathrm{mS} / \mathrm{cm}$ with one particularity: the conductivity of compost $\mathrm{N}^{\circ} 3$ is relatively high compared to the two other types of compost
(7.9 to 8.0$)$.

Table 1. $p H$ and electrical conductivity of composts.

\begin{tabular}{lllllll}
\hline & \multicolumn{7}{c}{$\mathbf{M} 3$} & \multicolumn{5}{c}{ M4 } \\
\cline { 2 - 7 } & $\mathbf{N}^{\circ} \mathbf{1}$ & $\mathbf{N}^{\circ} \mathbf{2}$ & $\mathbf{N}^{\circ} \mathbf{3}$ & $\mathbf{N}^{\circ} \mathbf{1}$ & $\mathbf{N}^{\circ} \mathbf{2}$ & $\mathbf{N}^{\circ} \mathbf{3}$ \\
\hline $\mathrm{Ph}$ & 8.3 & 8.2 & 8.1 & 8.0 & 8.1 & 8.1 \\
Conductivity $(\mathrm{mS} / \mathrm{cm})$ & 3.4 & 4.1 & 8.0 & 3.1 & 4.0 & 7.9 \\
\hline
\end{tabular}

M3: composts obtained after 3 months of composting-M4: composts obtained after 4 months of composting. 


\subsection{Evolution of Total Organic Carbon (TOC) and Nutrients of Composts}

\subsubsection{Total Organic Carbon (TOC)}

The content of the organic carbon of the various studied composts varies from 10.9 to $20.4 \%$ (Table 2). There is an increase in the organic carbon content of compost $\mathrm{N}^{\circ} 3$ while composts $\mathrm{N}^{\circ} 1$ and $\mathrm{N}^{\circ} 2$ decrease in their organic carbon content.

Table 2. Evolution of total organic carbon in composts.

\begin{tabular}{lll}
\hline & M3 (\%) & M4 (\%) \\
\hline $\mathrm{N}^{\circ} 1$ & 11.2 & 10.9 \\
$\mathrm{~N}^{\circ} 2$ & 12.8 & 12.4 \\
$\mathrm{~N}^{\circ} 3$ & 20.4 & 23.6 \\
\hline
\end{tabular}

Table 3. Content of major fertilizers in composts.

\begin{tabular}{lllllll}
\hline & $\mathbf{M 3}$ & \multicolumn{5}{c}{ M4 } \\
\hline & $\mathbf{N}^{\circ} \mathbf{1}$ & $\mathbf{N}^{\circ} \mathbf{2}$ & $\mathbf{N}^{\circ} \mathbf{3}$ & $\mathbf{N}^{\circ} \mathbf{1}$ & $\mathbf{N}^{\circ} \mathbf{2}$ & $\mathbf{N}^{\circ} \mathbf{3}$ \\
\hline N-NTK (\%) & 0.86 & 0.92 & 2.07 & 0.88 & 0.93 & 2.11 \\
P (\%) & 0.15 & 0.19 & 0.32 & 0.19 & 0.36 & 0.36 \\
$\mathrm{Ca}(\%)$ & 6.72 & 5.79 & 5.46 & 7.68 & 7.16 & 7.64 \\
$\mathrm{~K}(\%)$ & 0.88 & 0.99 & 1.84 & 0.96 & 1.09 & 1.98 \\
$\mathrm{Mg}(\%)$ & 0.25 & 0.26 & 0.64 & 0.30 & 0.30 & 0.67 \\
$\mathrm{Na}(\%)$ & 0.21 & 0.16 & 0.61 & 0.23 & 0.23 & 0.71 \\
\hline
\end{tabular}

\subsubsection{Nutrients in the Compost}

Table 3 shows the major nutrient contents of composts at the end of the $3 \mathrm{rd}$ and 4 th month of composting. Compost No. 3 has an NTK nitrogen content two times more than the other two types of compost (Table 3).

The three types of composts analyzed have a high content of $\mathrm{Na}, \mathrm{Mg}, \mathrm{K}$ and $\mathrm{Ca}$ (Table 3 ).

\subsubsection{C/N Ratio}

Table 4 presents the $\mathrm{C} / \mathrm{N}$ ratios of the composts obtained. There is a decrease in this ratio for compost $\mathrm{N}^{\circ} 1$ and $\mathrm{N}^{\circ} 2$ between the end of the 3rd and 4th month of composting (Table 4) and an increase in this ratio for compost $\mathrm{N}^{\circ} 3$.

Table 4. Evolution of the C/N ratio of composts.

\begin{tabular}{lll}
\hline & M3 (\%) & M4 (\%) \\
\hline $\mathrm{N}^{\circ} 1$ & 13.0 & 12.4 \\
$\mathrm{~N}^{\circ} 2$ & 13.9 & 13.3 \\
$\mathrm{~N}^{\circ} 3$ & 9.9 & 11.2 \\
\hline
\end{tabular}

\subsection{Content of Trace Elements in Metals}

According to Koledzi, 2011, the content of trace elements in metals of household waste composts from the city of Lomé is relatively high. However, the trace element contents of the three types of compost studied are far below the French and Swiss standards (Table 5).

Table 5. Contents in metallic trace elements of composts.

\begin{tabular}{|c|c|c|c|c|c|c|c|c|}
\hline \multicolumn{3}{|c|}{ M3 } & \multicolumn{3}{|c|}{ M4 } & \multicolumn{3}{|c|}{ Standards } \\
\hline & $\mathbf{N}^{\circ} 1$ & $N^{\circ} 2$ & $N^{\circ} 3$ & $\mathbf{N}^{\circ} \mathbf{1}$ & $\mathbf{N}^{\circ} 2$ & $\mathbf{N}^{\circ} 3$ & France & Switzerland \\
\hline $\mathrm{Pb}(\mathrm{mg} / \mathrm{kg})$ & 3.9 & 4.3 & 2.6 & 5.9 & 4.7 & 2.8 & 180 & 120 \\
\hline $\mathrm{Cd}(\mathrm{mg} / \mathrm{kg})$ & 0.7 & 0.1 & 0.0 & 0.0 & 0.3 & 0.0 & 3 & 2 \\
\hline $\mathrm{Cr}(\mathrm{mg} / \mathrm{kg})$ & 2.4 & 4.7 & 6.3 & 1.5 & 2.7 & 7.1 & 120 & 70 \\
\hline $\mathrm{Cu}(\mathrm{mg} / \mathrm{kg})$ & 30.5 & 17.4 & 19.0 & 17.5 & 16.9 & 16.9 & 100 & 100 \\
\hline $\mathrm{Zn}(\mathrm{mg} / \mathrm{kg})$ & 17.1 & 13.8 & 12.0 & 12.3 & 12.6 & 11.4 & 300 & 400 \\
\hline
\end{tabular}

\subsection{Evaluation of Maturity Using UV-Visible Spectroscopy of Composts}

Spectral analyzes by UV-visible provide information on the maturity of the composts, based on the degree of wetting of organic matter. UV-Visible spectroscopy is a technique used to characterize humic substances. The absorption of electromagnetic radiation in the UV regions (200 $\mathrm{nm}$ to $400 \mathrm{~nm}$ ) and visible (400 nm to $800 \mathrm{~nm}$ ) is associated with electronic transitions due to the excitation of an electron from a stable orbital to an unstable orbital [9].

\subsubsection{Evolution of the E4/E6 Absorbance Ratios of Composts}

The values of the E4/E6 ratio of the various composts studied are relatively low (Table 6). The value of the E4/E6 ratio decreases between the end of the 3rd and 4th month of the composting process for compost $\mathrm{N}^{\circ} 1$ while it increases for the two other types of compost (Table 6).
Table 6. E4/E6 compost produced ratios.

\begin{tabular}{lllll}
\hline & & E4 (465 nm) & E6 (665 nm) & E4/E6 \\
\hline \multirow{4}{*}{ M3 } & $\mathrm{N}^{\circ} 1$ & 0.079 & 0.032 & 2.469 \\
& $\mathrm{~N}^{\circ} 2$ & 0.091 & 0.043 & 2.116 \\
& $\mathrm{~N}^{\circ} 3$ & 0.069 & 0.024 & 2.875 \\
& $\mathrm{~N}^{\circ} 1$ & 0.055 & 0.025 & 2.200 \\
M4 & $\mathrm{N}^{\circ} 2$ & 0.035 & 0.011 & 3.182 \\
& $\mathrm{~N}^{\circ} 3$ & 0.040 & 0.010 & 4.000 \\
\hline
\end{tabular}

\subsubsection{Different Q2/Q6, Q2/Q4 and Q4/Q6 Absorbance Ratios of the Composts}

Table 7 presents the evolution of the absorbance ratios Q2/Q6, Q2/Q4 and Q4/Q6 of the composts obtained. The observation shows that the ratio Q2/Q6 is relatively high compared to the other ratios for the three types of compost.

There is also a decrease in the Q2/Q6, Q2/Q4 and Q4/Q6 ratios for composts No. 1. The Q2/Q6 and Q4/Q6 ratios also decrease for compost $\mathrm{N}^{\circ} 2$ but there is an increase in Q2/Q4 ratio. For compost $\mathrm{N}^{\circ} 3$ there is an increase in the Q2/Q6 and $\mathrm{Q} 4 / \mathrm{Q} 6$ ratios but a decrease in the Q2/Q4 ratio (Table 7). 
Table 7. Evolution of absorbance and absorbance ratios Q2/Q4, Q2/Q6 and Q4/Q6 of composts.

\begin{tabular}{|c|c|c|c|c|c|c|c|}
\hline & & Q2 (280 nm) & Q4 (472 nm) & Q6 (664 nm) & Q2/Q4 & Q2/Q6 & $\overline{Q 4 / Q 6}$ \\
\hline \multirow{3}{*}{ M3 } & $\mathrm{N}^{\circ} 1$ & 1.360 & 0.127 & 0.010 & 10.7 & 136.0 & 12.7 \\
\hline & $\mathrm{N}^{\circ} 2$ & 1.654 & 0.131 & 0.015 & 12.6 & 110.3 & 8.7 \\
\hline & $\mathrm{N}^{\circ} 3$ & 1.454 & 0.115 & 0.013 & 12.6 & 111.8 & 8.8 \\
\hline \multirow{3}{*}{ M4 } & $\mathrm{N}^{\circ} 1$ & 1.456 & 0.136 & 0.013 & 10.7 & 112.0 & 10.5 \\
\hline & $\mathrm{N}^{\circ} 2$ & 1.665 & 0.128 & 0.016 & 13.0 & 104.1 & 8.0 \\
\hline & $\mathrm{N}^{\circ} 3$ & 1.865 & 0.159 & 0.014 & 11.7 & 133.2 & 11.4 \\
\hline
\end{tabular}

\section{Discussion}

\subsection{Temperature Variation}

The evolution of temperature of the three composts under study clearly shows the main phases of composting (mesophilic, thermophilic, cooling and maturation) (Figure 2). It is noted that the starting temperature is almost the same $\left(37^{\circ} \mathrm{C}\right)$ for the three types of compost; this temperature being measured from the constitution of the windrows. The three types of compost have undergone a rapid change in temperature due to a very high activity of bacteria and fungi which break down simple compounds and certain polymers. These decompositions cause a rapid rise in heat of the compost in depth, up to $60^{\circ} \mathrm{C}$ in less than 5 days (very short mesophilic phase). On the one hand, Compost $\mathrm{N}^{\circ} 1$ and $\mathrm{N}^{\circ} 2$ have quickly reached an average temperature above $70^{\circ} \mathrm{C}$ after the 10th day of composting (thermophilic phase). The rise in temperature results in the replacement of mesophilic microorganisms with thermophilic microorganisms [2]. Compost $\mathrm{N}^{\circ} 3$ on the other hand practically had no temperature above $70^{\circ} \mathrm{C}$ but the values remained for a long time above $60^{\circ} \mathrm{C}$ (peak of $66^{\circ} \mathrm{C}$ ). This temperature was sufficient temperature to ensure a decomposition of the substrates and the destruction of living organisms. The difference in temperature between composts $\mathrm{N}^{\circ} 1$ and $\mathrm{N}^{\circ} 2$ on the one hand and compost $\mathrm{N}^{\circ} 3$ on the other hand is due to the carbon content of each substrate and to the composition of the original substrates of the composts. After 60 days of composting, composts $\mathrm{N}^{\circ} 1$ and $\mathrm{N}^{\circ} 2$ seem to have started the maturation phase. This process continued until the 107th day when the temperature was close to room temperature $\left(30^{\circ} \mathrm{C}\right)$. Compost $\mathrm{N}^{\circ} 3$ on the other hand has a temperature on the 107 th day still high $\left(40^{\circ} \mathrm{C}\right)$. It therefore still seems far from ambient temperature, synonymous with maturity.

\section{2. pH and Electrical Conductivity of Composts}

The values of $\mathrm{pH}$ after 3 months of composting (Table 1) corroborate the results recorded from 2012 to 2014 for 5 types of compost produced on the composting site of ENPRO NGOs in Lomé in Togo [10] (Koledzi et al., 2019). According to Albrecht (2007) and Aziablé et al. (2017) [11], this basic pH is believed to be responsible for the development of actinomycetes and alkaline bacteria. There is a decrease in $\mathrm{pH}$ for all composts due to the production of organic acids as a result of the breakdown of carbohydrates, fats and other substances. Also, the $\mathrm{CO}_{2}$ produced during aerobic degradation is more likely to promote the acidification of the environment. At this rate, it is probable that after a long composting time, a $\mathrm{pH}$ close to neutral as reported by Godden (1986) [12] and Gobat et al (1998) [13] can be expected. However, these values alone do not allow to show that composts have reached maturity. The fairly high conductivity of compost No. 3 ( 7.9 to 8.0 ) can be explained by the salinity of the substrate, especially sheep manure and poultry manure. During the maturation process the salinity decreases slightly until the 120th day of composting. These values show that all of the composts studied continue the maturation process.

\subsection{Evolution of Total Organic Carbon (TOC) and Nutrients of Composts}

The relatively high carbon content of Compost No. 3 (compared to the other two types of compost) is due to the composition of the substrate used (sheep manure and poultry manure). The organic carbon content of composts $\mathrm{N}^{\circ} 1$ and $\mathrm{N}^{\circ} 2$ decreased between the end of the 3rd and 4th month. Carbon is in fact used by microorganisms in the environment and is partly mineralized by carbon dioxide $\left(\mathrm{CO}_{2}\right)$. The organic carbon content of compost $\mathrm{N}^{\circ} 3$ has rather increased. The lack of maturity of this compost could explain this increase. Since the $\mathrm{pH}$ of composts is basic, there is no emission of volatile fatty acids which could occur in composts during fermentation in the event of incomplete oxidation of organic carbon.

The relatively high value of the NTK nitrogen content (Table 3) can be explained by the composition of the substrate (poultry manure) very rich in fermentable nitrogen. This increase in the nitrogen content is due to the degradation of the proteins of the substrate under the effect of heat and the action of microorganisms [2]. This is confirmed by the NTK nitrogen evolution data (Table 3) which indicates an increase in the nitrogen content between the end of the 3rd month and the end of the 4th month of composting for all the composts studied. Experimentally, the content of NTK nitrogen in dry matter generally tends to increase during fermentation and shows a relative stability in maturation. This increase is probably due in large part to the loss of dry mass [14]. We can infer a continuous breakdown of the three types of compost. The high content of $\mathrm{Na}, \mathrm{Mg}, \mathrm{K}$ and $\mathrm{Ca}$ from the composts produced (Table 3 ) is an asset for agricultural production. Nitrogen, phosphorus and potassium are the main nutrients needed for plant production. 
The contribution of the 5 elements N, P, K, Mg and Ca ensures the fertilization of crops. The $\mathrm{C} / \mathrm{N}$ ratios of compost $\mathrm{N}^{\circ} 1$ and $\mathrm{N}^{\circ} 2$ decrease between the end of the 3rd and 4th month of composting (Table 4). This is not the case for compost $\mathrm{N}^{\circ} 3$. Generally the $\mathrm{C} / \mathrm{N}$ ratio decreases during composting to reach values between 8 and 25. This decrease could correspond to an evolution of organic matter towards more stable and more humified forms [7]. The results of the work of some researchers indicate limit values for the end of composting: 19-24\% [1], 11$16 \%[15]$. While the NFU standard proposes $13 \% \mathrm{C} / \mathrm{N}$ ratio for mature compost, other scholars set the value at 20\% [16]. These limit values confirm that the $\mathrm{C} / \mathrm{N}$ ratios found for the three types of compost studied are entirely consistent with those of composts in the maturity phase. It can be concluded that composts $\mathrm{N}^{\circ} 1$ and $\mathrm{N}^{\circ} 2$ are in the maturity phase while compost $\mathrm{N}^{\circ} 3$ continues the fermentation phase.

\subsection{Content in Metallic Trace Elements of Composts}

The relatively low levels of trace metal elements of the various composts produced compared to French and Swiss standards (Table 5) can be explained by the direct collection of waste from households and the careful sorting carried out at the composting unit. Furthermore, composting reduces the content of metallic trace elements $[17,11,10,18]$. The three types of compost analyzed therefore pose no major risk to agriculture. However, repeated application of these composts could have a harmful effect on the biological functioning of the soil. These results corroborate those of Bokobana et al, 2017 [19].

\subsection{Evaluation of Maturity by UV-Visible Spectroscopy of Composts}

\subsubsection{Evolution of the E4/E6 Absorbance Ratios of Composts}

E4/E6 corresponds to the ratio of absorbance at 465 and 665 $\mathrm{nm}$. It evaluates the quality, the degree of condensation and the degree of aromatization of the organic matter in the compost. The E4 value provides information on size and molecular weight. E6, on the other hand, provides information on the degree of aromatic condensation and polymerization $[4,5]$. An E4/E6 ratio below 5 indicates the predominance of humic acids, consequently, an advanced decomposition while an E4/E6 ratio above 5 indicates the predominance of fulvic acids, therefore a less advanced decomposition [20]. The lower the ratio, the more mature the compost, the larger and more complex the humus particles. Conversely, the higher the ratio, the less the compost is ripe. Furthermore, a continuous decrease in this relationship over time is an additional factor in the maturity and stability of the compost [9].

Moreover, a decrease is observed in the absorbance ratio E4/E6 for compost $\mathrm{N}^{\circ} 1$ and an increase in this ratio for compost $\mathrm{N}^{\circ} 2$ and $\mathrm{N}^{\circ} 3$ from the end of the end of the 3rd and the 4 th month of composting (Table 6). These reports clearly indicate an increasing humification of compost $\mathrm{N}^{\circ} 1$ whereas composts $\mathrm{N}^{\circ} 2$ and $\mathrm{N}^{\circ} 3$ do not show a clear tendency. However, since the values of the E4/E6 ratios of the various composts studied are below 5 (Table 6), they confirm a predominance of humic acids for all the composts studied. They indicate therefore that a priori, the three types of compost are in the maturity phase.

\subsubsection{Evolution of the $Q 2 / Q 6, Q 2 / Q 4$ and $Q 4 / Q 6$ Absorbance Ratios of Composts}

The absorbance between $460 \mathrm{~nm}$ and $480 \mathrm{~nm}$ indicate the region of organic matter at the start of humidification and the absorbance between $600 \mathrm{~nm}$ and $670 \mathrm{~nm}$ correspond to highly humidified and condensed matter with abundant aromatic groups [9] (Ramdani, 2015). A decrease in the Q2/Q6 and Q4/Q6 ratios indicates an increase in the content of humified organic matter [9] (Ramdani, 2015) and therefore a more important humification process [3, 19]).

Although the values of the Q2/Q6 ratios appear relatively high (104.1 to 136.0), their evolution gives very interesting information on the degree of maturity of certain composts (Table 7).

The evolution of the Q2/Q4, Q2/Q6 and Q4/Q6 ratios of compost $\mathrm{N}^{\circ} 1$ (Table 7) and particularly Q2/Q6 and Q4/Q6 reveals an increase in highly humified organic matter within the compost and therefore the increasing humification of organic matter. These reports clearly indicate that the $\mathrm{N}^{\circ} 1$ compost is ripe.

The evolution of the Q2/Q6 and Q4/Q6 ratios of compost $\mathrm{N}^{\circ} 2$ indicates that compost $\mathrm{N}^{\circ} 2$ is also ripe.

The increase in Q2/Q6 and Q4/Q6 ratios indicates that compost $\mathrm{N}^{\circ} 3$ is not yet ripe.

\section{Conclusion}

Different parameters of composts maturity and stability were analyzed in this study (basic physico-chemical analyzes, UV-Visible spectroscopy). The data from the various elementary analyzes and particularly from UVVisible spectroscopy show that composts $\mathrm{N}^{\circ} 1$ and $\mathrm{N}^{\circ} 2$ can be considered ripe after 3 months of composting. The values of the various elementary analyzes clearly show that compost $\mathrm{N}^{\circ} 3$ is not yet ripe. Data show that composts from household and fruit waste reach maturity after three months while those from animal litter continue the process. Farmers' criticisms may therefore be related to compost from animal litter.

\section{Acknowledgements}

Our thanks go to the composting unit of the ENPRO NGO and to the various chemistry laboratories which served as a framework for carrying out the various elementary analyzes. They are:

1) chemistry laboratory of the Lycée français de Lomé,

2) Laboratoire de l'Hydrologie Appliquée et de l'Environnement (LHAE), Université de Lomé,

3) laboratoire de Gestion Traitement Valorisation des déchets (GTVD), Université de Lomé,

4) Laboratoire d'Assainissement en Sciences de l'Eau et de l'Environnement (LASEE), Université de Kara. 


\section{References}

[1] Koledzi K. E. (2011). Valorisation des déchets solides urbains dans les quartiers de Lomé (Togo): Approche méthodologique pour une production durable de compost. Mémoire de Thèse de Doctorat, 224 p. En ligne: http://www.theses.fr/2011LIMO4002.

[2] Albrecht R. (2007). Co-compostage de boues de station d'épuration et de déchets verts: Nouvelle méthodologie du suivi des transformations de la matière organique.

[3] Zbytniewski R., Buszewski B. (2005). Characterization of natural organic matter (NOM) derived from sewage sludge compost. Part 1: chemical and spectroscopic properties. Bioresource Technology, 96 (4), pp: 471-478. En ligne: https://doi.org/10.1016/j.biortech.2004.05.01.

[4] Chen J., LeBoeuf E. J., Dai S., Gu B. (2003): Composting of urban refuse in Labé (Guinea): process optimization and agricultural value; Chemosphere, 50: 639-647. En ligne: http://citeseerx.ist.psu.edu/viewdoc/download?doi=10.1.1.547 $.9518 \&$ rep $=$ rep $1 \&$ type $=$ pdf.

[5] Fuentes, M., González-Gaitano, G., García-Mina, J. M. (2006). The usefulness of UV-visible and fluorescence spectroscopies to study the chemical nature of humic substances from soils and composts. Organic Geochemistry 37, 12; 1949-1959.

[6] Koriko M., Tchegueni S., Koledzi K. E., Bafaï D., Zonvidey E., Tchangbedji G., Kili A. K., Hafidi M., 2013. Extractions et caractérisations physico-chimiques des substances humiques naturelles des sols et du compost. Int. J. Biol. Chem. Sci. 7 (3): 1405-1415. $\quad$ En ligne: http://citeseerx.ist.psu.edu/viewdoc/download?doi=10.1.1.100 $2.9671 \&$ rep $=$ rep $1 \&$ type $=$ pdf.

[7] Abaker M.G. (206). Suivi de maturation de composts mixtes par spectrométrie d'absorption et de fluorescence UV-Vis. Mémoire de thèse de Doctorat 209p. En ligne: https:www.theses.fr/2016TOUL0019.pdf.

[8] Schnitzer M. (1982). Organic matter characterization. pages 581-595 in Page

[9] Ramdani N. (2015). Transformation de la matière organique au cours du co-compostage de boues de stations d'épuration et de déchets verts: approche expérimentale pour une production durable de compost. Mémoire de thèse de doctorat, P169-171. En ligne: https://theses.univoran1.dz/document/11201550t.pdf.

[10] Koledzi K. E., Aziablé E., Megnassan S. (2019). Comparative study of the evolution of mass balance on the ENPRO composting platform in Togo. Journal of Chemical, Biological and Physical Sciences Section D; November 2018-January 2019, Vol. 9, No.1; 127-137. En ligne: doi:10.24214/jcbps.d.9.1.12737.
[11] Aziable E., Tchegueni S., Bodjona M. B., Degbe A. K., Zamama M., Hafidi M., EL Meray M., Kili K. A. ( 2017): Valorization of agro-industrial waste by bio-process aerobic “composting”. JMES, 2017, 8 (4), pp. 1277-1283.

[12] Godden B. (1986). Etude du processus de compostage du fumier de bovin. Thèse de doctorat en Sciences Agronomiques, Université Libre de Bruxelles. Laboratoire de microbiologie, $136 \mathrm{p}$.

[13] Gobat J. M., Aragno M., Matthey W. (1998). Le sol vivant. Bases de la pédologie. Biologie des sols. Presses Polytechniques et Universitaires Romandes. Collection Gérer l'Environnement $N^{\circ} 14$. Lausanne, Suisse, 519 pages.

[14] Tremier A., De Guardia A., Maillard P. (2007). Indicateurs de stabilisation de la matière organique au cours du compostage et indicateurs de stabilité des composts: analyse critique et perspectives d'usage. TSM numéro 10-2007-102ème année. P 105-123. En ligne: http://tsm.astee.org ou http://dx.doi.org/10.1051/tsm/200710105.

[15] Matejka, G., Barbier, J., De Las Heras, F., Klein, A., Paqueteau, F., Kebe, A. (2001). Composting of urban refuse in Labé (Guinea): process optimization and agricultural value;bCagliari (Sardinia) Eighth International Waste Management and Landfill Symposiuim (CISA: Environ. Sanitary Engineering Centre) 1-5 Oct. 2001.

[16] Chitsan, L. (2008). A negative-pressure aeration system for composting food wastes. Bioresource Technology 99 (2008) 7651-7656. En ligne: https://www.sciencedirect.com/science/article/pii/S096085240 8001144?via\%3Dihub.

[17] Aziablé E., Kolédzi E. K. (2018): Study of Agronomic and Environmental Profile of Compost and Fine Fraction Produced and Stored in a Shed at Composting Site: ENPRO Composting Site, Lomé, Togo. Science Journal of Chemistry 2018; 6 (5): 95-98.

[18] Pakou C., Kornaros M., Stamatelatou K., Lyberatos G. (2009). On the fate of LAS, NPEOs and DEHP in municipal sewage sludge during composting. Bioresour. Technol., 100, pp: 16341642. DOI: https://doi.org/10.1016/j.biortech.2008.09.025.

[19] Bokobana A., Toundou O., Kolani L., Amouzouvi K., A., A., Koledzi E., Tozo K., Tchangbedji G.(2017). Traitement de déchets ménagers par co-compostage avec la légumineuse Cassia occidentalis L. et quelques adjuvants de proximité pour améliorer la qualité agronomique de composts. Déchets Sciences et Techniques-Nº73-Mai 2017. https://doi.org/10.4267/dechets-sciences-techniques.3551.

[20] Achour, F., Thèse (2008). Caractérisation de la matière organique dans les ordures ménagères. Recherche d'indicateurs de stabilité. Institut National des Sciences Appliquées de Lyon (France), 175 p. 